Trauma Surgery \& Acute Care Open

\title{
Necrotizing fasciitis following abdominal gunshot wound
}

\author{
Eliza Moskowitz, ${ }^{1,2}$ Thomas Schroeppel $^{1}$
}

'Department of Surgery, Memorial Hospital, Colorado Springs, Colorado, USA 2Department of Surgery, University of Colorado School of Medicine, Aurora, Colorado, USA

Correspondence to Dr Eliza Moskowitz, Department of Surgery, Memorial Hospital, Colorado Springs CO 80045,

USA; eliza.moskowitz@ ucdenver.edu

Received 2 January 2018 Revised 7 January 2018 Accepted 9 January 2018
To cite: Moskowitz $\mathrm{E}$, Schroeppel T. Trauma Surg Acute Care Open 2018;3:1-2.
A 39-year-old man presented to our hospital as a trauma activation following multiple gunshot wounds to the abdomen. He was taken to the operating room (OR) where abdominal exploration revealed multiple small and large intestinal injuries. The injured segments of the distal small bowel and proximal colon were resected and bowel continuity was restored. Additionally, a smaller sigmoid colon injury near the level of the sacral promontory was identified and primarily repaired. The multiple missile sites were not aggressively debrided, but were irrigated and left to close by secondary intent. Perioperative antibiotics were continued for 24 hours given intra-abdominal contamination. The patient continued his recovery in the surgical intensive care unit (SICU). On postoperative day (POD) 2, he remained hypotensive despite vasopressor support and began to clinically deteriorate. As such, he was taken back to the OR for re-exploration. Intact anastomoses and colorrhaphy were appreciated.

On POD 10 from his initial laparotomy, he developed cellulitis and an abdominal wall abscess. $\mathrm{He}$ was taken to the OR for incision and debridement (I\&D) of that abscess. After the I\&D, a course of postoperative antibiotics was initiated. On POD 13, the patient continued to decompensate and had developed bullae along his abdominal wall and flank.

\section{WHAT WOULD YOU DO?}

A. Initiate broad-spectrum antibiotics and continue to closely monitor in the SICU.

B. Obtain soft tissue biopsy, initiate topical steroid treatment, and consult dermatology due to concern for possible Steven-Johnson syndrome.

C. Return to the OR for debridement given concern for necrotizing soft tissue infection (NSTI).

\section{WHAT WE DID AND WHY}

\section{Correct answer $\mathrm{C}$}

On POD 13, the patient was urgently returned to the OR for re-exploration with incision and extensive debridement. The patient's abdominal fascia was now necrotic. The extent of the necrosis involved the abdominal wall, flank, and right thigh. This necrotizing infection, which appeared nearly 2 weeks after the patient's initial insult, could have originated at a missile wound that occurred 2 weeks earlier. Debridement of the missile wound sites at the time of initial injury is not within the usual standards of our practice. Moreover there were over a dozen wounds, and debriding the wounds/ tracts would have resulted in the removal of large amounts of abdominal wall at the time of the initial operation. The patient was taken back to the $\mathrm{OR}$ numerous times for washouts and debridements once the diagnosis was confirmed. After infection control was obtained, the vasopressor requirement improved and he began to convalesce. Subsequent transfer to a tertiary burn center was completed for skin grafts and soft tissue reconstruction. He was discharged home 6 weeks after his initial injury with all wounds covered.

NSTIs include necrotizing cellulitis, myositis, and fasciitis. ${ }^{1}$ Necrotizing fasciitis is an infection of the deeper tissues resulting in rapid, progressive, fulminant tissue destruction with resultant high morbidity and mortality (9\%-25\%). ${ }^{2}$ Obesity, diabetes, immunosuppression, history of intravenous drug abuse, and increased age all contribute to the risk of NSTI development. ${ }^{3}$

The diagnosis is mainly clinical, as there are no specific imaging or laboratory values that have been proven to be diagnostic. Coagulopathy, hyponatremia, leukocytosis, and elevations in creatinine, glucose, lactate, CRP, erythrocyte sedimentation rate, and creatine kinase can be seen. A score (laboratory risk indicator for necrotizing fasciitis (LRINEC)) can be calculated based on these laboratory parameters..$^{4}$ Subsequent validation failed to prove LRINEC to be an accurate tool for risk stratification due to its low predictive value, high false-positive, and false-negative rates. ${ }^{6-9}$

Treatment entails emergent, rapid surgical debridement of all involved tissues. Intraoperative findings include edematous and grayish appearing fascia, thin exudate, and easy separation of fascial planes. Aggressive debridement should be pursued and continued until bleeding viable tissue is appreciated. ${ }^{8}$ Eventual tissue reconstruction using grafts or flaps may be pursued. For severe NSTIs involving the extremities, amputation may be considered.

Initial antibiotic therapy should include agents against Gram-positive, Gram-negative, and anaerobic organisms. Consideration should be given to ensure coverage against group A Streptococcus and Clostridium. Antibiotics should be continued until no further debridements are necessary, and the patient's hemodynamic status has normalized.

Elapsed time between onset of symptoms and initial debridement is the most important factor affecting morbidity and mortality. ${ }^{10}{ }^{11}$ If operation is delayed more than 12 hours, increased morbidity and mortality ensue. ${ }^{12}$ Delayed debridement is associated with a ninefold mortality increase. ${ }^{5}$ Although the presentation was not classic in this case for timing or symptoms for NSTI, aggressive surgical control of 
the infection with supplemental antibiotics led to resolution of the infection and subsequent reconstruction.

Contributors Drafting of manuscript: EM and TS. Critical edits: TS.

Funding This research received no specific grant from any funding agency in the public, commercial or not-for-profit sectors.

Competing interests None declared.

Provenance and peer review Not commissioned; externally peer reviewed.

Open Access This is an Open Access article distributed in accordance with the Creative Commons Attribution Non Commercial (CC BY-NC 4.0) license, which permits others to distribute, remix, adapt, build upon this work non-commercially, and license their derivative works on different terms, provided the original work is properly cited and the use is non-commercial. See: http://creativecommons.org/ licenses/by-nc/4.0/

(c) Article author(s) (or their employer(s) unless otherwise stated in the text of the article) 2018. All rights reserved. No commercial use is permitted unless otherwise expressly granted.

\section{REFERENCES}

1 Pasternack MS, Cellulitis SMN. Necrotizing fasciitis, and subcutaneous tissue infections. In: Bennett JE, Dolin R, Blaser MJ, eds. Mandell, Douglas, and Bennett's Principles and Practice of Infectious Diseases. 8th. Philadelphia, Churchill Livingstone, 2015.

2 Kao LS, Lew DF, Arab SN, Todd SR, Awad SS, Carrick MM, Corneille MG, Lally KP. Loca variations in the epidemiology, microbiology, and outcome of necrotizing soft-tissue infections: a multicenter study. Am J Surg 2011;202:139-45.
3 Elliott DC, Kufera JA, Myers RA. Necrotizing soft tissue infections. Risk factors for mortality and strategies for management. Ann Surg 1996;224:672-83.

4 Wong CH, Khin LW, Heng KS, et al. The LRINEC (Laboratory Risk Indicator for Necrotizing Fasciitis) score: a tool for distinguishing necrotizing fasciitis from other soft tissue infections. Crit Care Med 2004;32:1535-41.

5 Wong CH, Khin LW. Clinical relevance of the LRINEC (Laboratory Risk Indicator for Necrotizing Fasciitis) score for assessment of early necrotizing fasciitis. Crit Care Med 2005:33:1677.

6 Wilson MP, Schneir AB. A case of necrotizing fasciitis with a LRINEC score of zero: clinical suspicion should trump scoring systems. J Emerg Med 2013:44:928-31.

7 Neeki MM, Dong F, Au C, Toy J, Khoshab N, Lee C, Kwong E, Yuen HW, Lee J, Ayvazian A et al. Evaluating the Laboratory Risk Indicator to Differentiate Cellulitis from Necrotizing Fasciitis in the Emergency Department. West J Emerg Med 2017; 18:684-9.

8 Hakkarainen TW, Kopari NM, Pham TN, Evans HL. Necrotizing soft tissue infections: review and current concepts in treatment, systems of care, and outcomes. Curr Prob/ Surg 2014:51:344-62.

9 McHenry CR, Piotrowski JJ, Petrinic D, Malangoni MA. Determinants of mortality for necrotizing soft-tissue infections. Ann Surg 1995;221:558-65.

10 Bilton BD, Zibari GB, McMillan RW, Aultman DF, Dunn G, McDonald JC. Aggressive surgical management of necrotizing fasciitis serves to decrease mortality: a retrospective study. Am Surg 1998:64:397-400.

11 V K, Hiremath BV, V A I. Necrotising soft tissue infection-risk factors for mortality. J Clin Diagn Res 2013:7:1662-5.

12 Sudarsky LA, Laschinger JC, Coppa GF, Spencer FC. Improved Results from a Standardized Approach in Treating Patients with Necrotizing Fasciitis. Ann Surg 1987;208:661-5. 